\title{
PREVALENSI MALNUTRISI PADA LANSIA DENGAN PENGUKURAN MINI NUTRITIONAL ASSESMENT (MNA) DI PUSKESMAS
}

\author{
Elman Boy ${ }^{1}$ \\ ${ }^{\text {I} B a g i a n ~ I l m u ~ K e s e h a t a n ~ M a s y a r a k a t ~ F a k u l t a s ~ K e d o k t e r a n ~ U n i v e r s i t a s ~ M u h a m m a d i y a h ~ S u m a t e r a ~ U t a r a ~}$ \\ Email: elmanboy@umsu.ac.id
}

\begin{abstract}
Elderly is the final phase of human life resulting in a decline in organ function. Malnutrition is a problem that often occurs in the elderly. This is due to insufficient energy and protein intake. This study aims to determine the results of the use of the nutritional- instruments-status of geriatric patients in the Kota Matsum Health Center in Medan in 2018. This study has categorized categorical descriptive research carried out by cross sectional, the sample has been taken using the Slovin formula chosen by consecutive sampling. The number of samples taken was 93 people. In this study the most respondents were found at the age of 60-74 years $(89.3 \%)$ and based on sex were women (54.8\%). Nutritional status based on IMT found that the highest number of respondents with nominal nutrition (64.5\%) and based on MNA found the most results in respondents with a risk of malnutrition $(59.2 \%)$. In this study the highest results were found at the age of 64-70 years and women were more than men. In terms of nutritional status, there are many results found and those at risk of malnutrition.
\end{abstract}

Keywords: elderly, nutritional status, malnutrition

\begin{abstract}
ABSTRAK
Lansia merupakan fase akhir kehidupan manusia sehingga terjadi penurunan fungsi organ. Kurang gizi merupakan masalah yang sering terjadi pada lansia. Hal ini akibat tidak tercukupinya asupan energi dan protein. Penelitian ini bertujuan untuk mengetahui mengetahui hasil penggunaan instrumen pengkajian status gizi pasien geriatri di Puskesmas Kota Matsum Kota Medan tahun 2018. Penelitian ini adalah penelitian deskriptif kategorik yang dilakukan secara cross sectional, sampel diambil menggunakan rumus Slovin dipilih secara consecutif sampling. Jumlah sampel sebanyak 93 orang. Pada penelitian ini didapati responden tebanyak pada usia 60-74 tahun (89,3\%) dan berdasarkan jenis kelamin adalah perempuan (54,8\%). Status gizi berdasarkan IMT didapati hasil terbanyak responden dengan gizi nomal $(64,5 \%)$ dan berdasarkan MNA didapati hasil terbanyak pada responden dengan resiko malnutrisi (59,2\%). Pada penelitian ini didapati hasil terbanyak pada usia 64-70 tahun dan perempuan lebih banyak dari pada laki-laki. Dilihat dari segi status gizi, didapati hasil tebanyak dan yang beresiko malnutrisi.
\end{abstract}

Kata Kunci: Lansia, Status Gizi, MNA, Malnutrisi

\section{PENDAHULUAN}

Lansia merupakan fase akhir kehidupan manusia, setiap insan yang berumur pasti akan melewati fase ini. Semakin bertambahnya usia maka seluruh fungsi organ telah mencapai puncak maksimal sehingga yang terjadi sekarang adalah penurunan fungsi organ. ${ }^{1}$

Diseluruh dunia penduduk lansia tumbuh dengan sangat cepat bahkan tercepat dibandingkan kelompok usia lainnya. ${ }^{2}$ Menurut Undang-Undang Republik Indonesia Nomor 13 Tahun 1998 tentang Kesejahteraan Lanjut Usia, yang dimaksud dengan
Lanjut Usia (lansia) adalah seseorang yang telah mencapai usia 60 tahun keatas Pada tahun 2013 jumlah penduduk lansia di seluruh dunia berjumlah 7,2 milyar. Jumlah penduduk lansia dengan jenis kelamin perempuan berjumlah 10.046.073 jiwa, sedangkan jumlah penduduk lansia dengan jenis kelamin pria berjumlah 8.538.832 jiwa. $^{3}$ Berdasarkan data proyeksi penduduk, diperkirakan tahun 2017 terdapat 23,6 juta jiwa penduduk lansia di Indonesia (9,03\%). Pada tahun 2015 angka kesakitan lansia di perkotaan adalah sebesar $26,89 \% .^{2,3}$ 
Kesehatan lansia pada dasarnya terletak pada status gizinya.Kurang gizi merupakan salah satu masalah gizi yang sering terjadi pada lansia.Kejadian ini belum Nampak secara jelas hingga lansia tersebut.

jatuh dalam kondisi gizi buruk.Hal ini sebagai akibat tidak tercukupi asupan energi dan protein. Orangorang tua pada umumnya menderita kekurangan gizi makro dan mikro akan memilii respon sistem dan fungsi imun yang rendah. Jika fungsi imun lansia dapat ditingkatkan, maka kualitas hidup lansia meningkat sehingga dapat menjadi lansia yang sehat, mandiri berdaya guna tidak menjadi beban buat keluarga ataupun masyarakat serta dapat menekan pelayanan kesehatan. ${ }^{1,2}$

\section{METODE PENELITIAN}

Penelitian ini merupakan penelitian deskriptif kategorik dengan desain Cross Sectional yang bertujuan untuk Skrining Status Gizi Pasien lanjut usia di puskesmas Kota Matsum. Pelaksanaan penelitian ini dilakukan di Puskesmas Kota Matsum, Kecamatan Medan Area Kota Medan mulai 18 September 2018 - 5 Oktober 2018. Pemilihan sampel penelitian dengan menggunakan metode Slovin. Sampel yang telah diambil akan diuji sesuai dengan kriteria inklusi dan eksklusi:

Kriteria inklusi:

- Pasien lansia yang berobat ke puskesmas.

- Pasien lansia yang bersedia menjadi sampel dan menandatangani informed consentserta bersedia untuk diwawancara untuk pengisian kuisioner.

Kriteria eksklusi:

- Data yang tidak lengkap

\section{Teknik Pengumpulan Data}

Penelitian ini menggunakan data primer, yaitu dikumpulkan secara langsung oleh peneliti, berupa hasil wawancara sesuai kuisioner MNA dan pengukuran berat badan serta tingi badan untuk menentukan indeks massa tubuh dan data sekunder, yaitu data yang diperoleh dari puskesmas Kota Matsum berupa jumlah populasi lansia yang terdaftar.

\section{Analisis Data}

Semua data yang telah terkumpul diolah dan disusun dalam bentuk tabel dan grafik distribusi frekuensi dan penjelasan mengenai data akan disajikan dalam bentuk narasi.

\section{HASIL}

Tabel 1. Distribusi responden berdasarkan jenis kelamin

\begin{tabular}{lll}
\hline Jenis kelamin & Frekuensi & Persentase (\%) \\
\hline Laki-Laki & 42 & 45,2 \\
Perempuan & 51 & 54,8 \\
\hline Total & 93 & 100 \\
\hline
\end{tabular}

Pada tabel 1 di atas menunjukkan dari 93 responden menunjukkan bahwa jenis kelamin responden yang paling banyak adalah berjenis kelamin perempuan yaitu sebanyak 51 orang $(54,8 \%)$, kemudian berjenis kelamin laki-laki sebanyak 42 orang $(45,2 \%)$.

Tabel 2. Status IMT berdasarkan kelompok usia Lansia

\begin{tabular}{|c|c|c|c|c|c|c|c|}
\hline \multirow{3}{*}{ Usia } & \multicolumn{6}{|c|}{ IMT } & \multirow{3}{*}{$\begin{array}{l}\text { Total } \\
(\%)\end{array}$} \\
\hline & \multicolumn{2}{|c|}{$\begin{array}{l}\text { Gizi } \\
\text { kurang } \\
(<18,5)\end{array}$} & \multicolumn{2}{|c|}{$\begin{array}{l}\text { Gizi } \\
\text { Normal } \\
(\mathbf{1 8 , 5 - 2 5 )}\end{array}$} & \multicolumn{2}{|c|}{$\begin{array}{l}\text { Obesitas } \\
(>25)\end{array}$} & \\
\hline & $\mathrm{n}$ & $\%$ & $\mathrm{n}$ & $\%$ & $\mathrm{n}$ & $\%$ & \\
\hline $60-74$ & 6 & 7,3 & 51 & 62,2 & 25 & 30,5 & 100 \\
\hline $75-90$ & 1 & 9,5 & 9 & 81 & 1 & 9,5 & 100 \\
\hline$>90$ & 0 & & 0 & & 0 & & 0 \\
\hline Jumlah & 7 & 7,5 & 60 & 64,5 & 26 & 28 & 100 \\
\hline
\end{tabular}


Berdasarkan tabel diatas di peroleh responden terbanyak dengan kategori lanjut usia sebanyak 82 orang $(88,2 \%)$, lanjut usia tua sebanyak 11 orang $(11,8 \%)$ dan kategori sangat tua tidak dijumpai (0\%). Pada distribusi berdasarkan Indeks Massa Tubuh (IMT) didapatkan hasil yang terbanyak yaitu gizi normal sebanyak 60 orang $(64,5 \%)$ kemudian obesitas sebanyak 26 orang (28\%) kemudian gizi kurang sebanyak 7 orang $(7,5 \%)$.

Tabel 3. Distribusi status gizi Lansia berdasarkan status gizi menurut MNA

\begin{tabular}{lll}
\hline Status Gizi & Frekuensi & $\begin{array}{l}\text { Persentase } \\
(\%)\end{array}$ \\
\hline Tidak & & \\
berisiko & 35 & 37,6 \\
malnutrisi & 55 & 59,2 \\
Risiko & 3 & 3,2 \\
Malnutrisi & & \\
Malnutrisi & & 100 \\
\hline Total & 93 &
\end{tabular}

Dari tabel di atas tampak distribusi status gizi menurut MNA (Mini Nutrritional Assesment) yaitu sebanyak 55 orang $(59,2 \%)$ yang memiliki resiko malnutrisi, sebanyak 35 orang $(37,6 \%)$ yang tidak berisiko malnutrisi dan sebanyak $3(3,2 \%)$ orang yang mengalami malnutrisi.

\section{PEMBAHASAN}

Penelitian ini membahas mengenai karakteristik lansia yang mencakup usia, jenis kelamin, indeks masa tubuh dan status nutrisi. Dari penelitian ini, bahwa rasio lansia berjenis kelamin perempuan lebih tinggi dibandingkan dengan pria $(54,8 \%: 45,2 \%)$. Hal ini sesuai dengan data statistik di Indonesia yang menyatakan lansia didominasi oleh wanita karena berhubungan dengan usia harapan hidupnya yang lebih tinggi. ${ }^{21,22}$ kategori dengan usia 60-74 tahun merupakan kategori usia dengan jumlah terbanyak.Hasil ini sejalan dengan penelitian yang dilakukan oleh Joymati O, dkk di India pada tahun 2018 dengan hasil responden paling banyak adalah berusia 60-74 tahun. ${ }^{22}$ Berdasarkan distribusi IMT gizi normal adalah yang terbanyak yaitu 60 orang $(64,5 \%)$. Penelitian ini sejalan dengan penelitian yang dilakukan oleh Sharuna Ghimire, dkk di Nepal tahun 2017 dengan hasil yang menunjukkan bahwa rata rata responden memiliki IMT normal $(18,5-$ $22,9 \mathrm{~kg} / \mathrm{m}^{2}$ ). Penelitian ini juga sesuai dengan penelitian yang dilakukan oleh Chaitra Vinod Khole, dkk di India tahun 2018 bahwa IMT normoweight adalah hasil terbanyak dengan jumlah 71 dari 131 responden. ${ }^{23}$ Beberapa penelitian tidak sejalan dengan penelitian ini seperti penelitian yang dilakukan oleh David R. Buys, dkk di Amerika Serikat pada tahun 2014 dan penelitian yang dilakukan oleh Davorka Vrdoljak,dkk di Kroasia pada tahun 2014 dimana hasil penelitian menunjukkan bahwa responden terbanyak dengan IMT overweight. ${ }^{24}$ Dari segi status gizi menurut MNA menunjukkan bahwa status gizi responden yang paling banyak adalah yang memiliki risiko malnutrisi yaitu sebanyak 55orang $(59,2 \%)$, kemudian diikuti oleh responden yang tidak berisiko malnutrisi sebanyak 35 orang $(37,6 \%)$ dan yang mengalami malnutrisi sebanyak 3 orang (3,2\%). Penelitian ini sejalan dengan hasil penelitian yang dilakukan oleh Surajit Lahiri, dkk di India pada tahun 2014 yaitu sebanyak 143 (61\%) dari 235 lansia memiliki status nutrisi yang baik berdasarkan MNA. ${ }^{25}$ Pada pengkajian MNA ini terdapat beberapa faktor yang mempengaruhi lansia berada dalam risiko malnutrisi. Faktor-faktor tersebut adalah lingkungan/tempat tinggal, terapi pengobatan, adanya luka tekan, frekuensi makan setiap hari, jenis asupan protein, konsumsi sayur atau buah, asupan cairan, cara makan, persepsi lansia tentang status gizi dan kesehatannya. ${ }^{26}$

\section{SIMPULAN}

Berdasarkan uraian hasil dan pembahasan yang telah dijelaskan pada bab sebelumnya, maka dapat diambil kesimpulan sebagai berikut : 
1. Lansia yang menjadi responden di Puskesmas Kota Matsum pada tahun 2018 menunjukkan bahwa resonden paling banyak adalah berjenis kelamin perempuan yaitu $54,8 \%$.

2. Lansia yang menjadi responden di Puskesmas Kota Matsum pada tahun 2018 adalah responden yang tergolong kategori lanjut usia yaitu $89,3 \%$.

3. Lansia yang menjadi responden di Puskesmas Kota Matsum pada tahun 2018 adalah distribusi IMT dengan gizi normal sebanyak $64,5 \%$.

4. Hasil yang didapati dari Mini Nutritional Assessment (MNA) pada lansia di puskesmas kota matsum pada tahun 2018 menunjukkan bahwa status gizi responden yang paling banyak adalah yang memiliki risiko malnutrisi yaitu sebanyak $59,2 \%$.

\section{DAFTAR PUSTAKA}

1. Lestari SR, Aris R. 2014. Gambaran Asupan Potein Zat Mikro, Status Gizi, Dan Kualitas Hidup Lansia Di Desa Tupabiring Kecamatan Bontua Kabupaten Maos. Makasar: Media Gizi Pangan. Vol XVIII, Edisi 2

2. Infodatin, Pusat data dan Informasi Kementrian Kesehatan RI. 2017. Situasi dan analisa lanjut uji.

3. Lansia Kementrian Kesehatan RI Pusat Data dan Infomasi, Jakarta Selatan - Tahun 2017. Analisis Lansia di Indonesia (Analisis Lansia Indonesia 2017)

4. Rahmawati Y. Body Mass Index (BMI), Berat Badan, Tinggi Badan dan Fat Skinfold Perempuan $>60$ Tahun di Panti dan Perkumpulan Lanjut Usia di Surabaya. Universitas Hang Tuah. 2012

5. Setiati S, Harimurti K, Dewiasty E, Istanti R, Sari W, Verdinawati T. 2013. Prevalensi geriatric giant dan kualitas hidup pada pasien usia lanjut yang dirawat di Indonesia: penelitian multisenter. In Rizka A (editor). Comprehensive prevention \& management for the elderly: interprofessional geriatric care. Jakarta: Perhimpunan Gerontologi Medik Indonesia:183

6. Darmojo,Boedhi dan Hadi Martono.2006.Geriatri (Ilmu Kesehatan Usia Lanjut).edisi ke-5.Jakarta : FK-UI.

7. Indria,Y.2012.Gerontologi dan Progeria.Cetakan I.Yogyakarta : Pustaka Pelajar.

8. Nugroho,W. 2012. Keperawatan Gerontik dan Geriatrik. Jakart : EGC

9. Penilalaian status gizi/kementrian kesehatan republic Indonesia, tahun 2017/pusat pendidikan sumber daya manusia kesehatan.

10. Kemenkes RI. 2013. Pelayanan gizi rumah sakit.

11. Dinas Kesehatan Provinsi Sumatera Utara, 2006. Profil Pembinaan Kelompok Usia Lanjut di Sumatera Utara. Medan.

12. Supariasa, 2001. Penilaian Status Gizi. EGC. Jakarta

13. Siregar Arifin, 2000. Upaya Perbaikan Gizi Lansia. Fakultas Kesehatan Masyarakat USU Bagian Gizi Masyarakat. Medan.

14. Pranarka, Kris. 2011. Simposium geriatric syndromes: revisited. Semarang: Badan Penerbit Universitas Diponegoro.

15. Dini, AA. 2013. Sindrom geriatri. Lampung: Fakultas Kedokteran Universitas Lampung. Medula, Volume 1, Nomor 3.

16. HS Ibrahim. 2012. Correlation between Factors Affecting Nutritional Needs With Nutrition Status of Elders Residing in UPTD Rumoh Seujahtera Geunaseh Sayang, Banda Aceh. Idea Nusing Jounal. 
17. Rohmawati N. 2015. Tingkat Kecemasan, Asupan Makan, Dan Status Gizi Pada Lansia Di Kota Yogyakarta. Jurnal Gizi Klinik Indonesia.

18. Martono, Hadi dan Pranarka. 2009. Geriatri Ilmu Kesehatan Usia Lanjut Edisi 4. Jakarta:Balai Penerbit FKUI

19. Priyanka Bhandari, Rani Bagga, Doeki Nandan. 2010. Pola Pelayanan Lanjut Usia Vol 12.

20. Sigh, R and S.Dixit. 2010. Pendekatan Komprehensif Terhadap Pelayanan Kesehatan Pada Usia Lanjut Vol 13.

21. Ghimire S, Baral BK, Callahan K. 2017. Nutritional Assessment of CommunityDwelling Older Adults In Rural Nepal. Plos one journal.

22. Joymati O, Ningombam M, Rajkumari B. 2018. Assessment Of Nutritional Status Among Elderly Population In A Rural Area In Manipur: Community-Based Cross-Sectional Study. International Journal of Community Medicine and Public Health.

23. Khole CV, Soletti A. 2018. Nutritional Status of Elderly in the Old Age Homes: A Study in Pune City. Scopus journal metics.

24. Lee G, Park J, Oh SW, Kim J. 2017. Association between Body Mass Index and Quality of Life in Elderly People over 60 Years of Age. Korean Journal of Family Medcine (KJFM). 181-191

25. Cetin DC, Nasr G. 2014. Obesity in Elderly: More Complicated than What You Think. Cleveland Clinic Journal of Medicine. Volume 81.

26. Buys DR, Roth DL, Ritchie CS, Sawyer P, Allmen RM. 2014. Nutritional Risk And Ody Mass Index Predict Hospitalization, Nursing Home Admissions, And Mortality In
Community-Dwelling Older Adults: Results From the UAB Study of Aging With 8,5 Years of Follow Up. The Journal Of Gerentology. Volume 69. 